\title{
Resíduos oriundos das indústrias na cidade de Apodi-RN: caracterização do descarte e seu uso na prática da reciclagem pela comunidade escolar
}

Industries waste obtained by Apodi city: disposal characterization and its use in recycling practice by school community

\author{
Láiza Cristina Carlos Freire', Mayk Henrique Gomes de Oliveira², Dennis Rodrygo Marinho de Oliveira ${ }^{3}$, \\ Leonardo Alcântara Alves ${ }^{4}$ \\ 1,2,3,4 Instituto Federal de Educação, Ciência e Tecnologia do Rio Grande do Norte, Brasil
}

\section{Resumo}

Os problemas gerados pelas diferentes formas de descartes incorretos do lixo industrial vêm crescendo de forma considerável nos últimos anos, devido à falta de consciência dos gestores responsáveis por essas indústrias. O presente trabalho, objetiva identificar os principais resíduos oriundos das indústrias da cidade de Apodi-RN, bem como o descarte/manejo correto dos mesmos, além de levar a classe estudantil a conscientização sobre a prática da reciclagem utilizando os próprios resíduos das indústrias locais. Para tanto, foi realizado inicialmente um estudo a partir de uma análise preliminar do gerenciamento de resíduos nas indústrias e identificação dos mesmos, como também uma oficina em Escola pública da região.

Palavras-chave: Indústrias. Resíduos Industriais. Educação Ambiental. Reciclagem.

\begin{abstract}
Problems generated by different forms of incorrect disposal of industrial wastes have grown considerably in recent years due to lack of managers awareness responsible for these industries. The present study aims to identify the most common industries residues originating from Apodi city as well as the disposal/correct handling of them, besides taking the class student awareness about the practice of using their own recycling waste from local industries. For this purpose, initially, a study was conducted by a preliminary waste management analysis in industries and identify them, as well as a workshop in a public school in the region.
\end{abstract}

Keywords: Industries. Industrial Waste. Environmental Education. Recycling. 


\section{INTRODUÇÃO}

Hoje vivencia-se uma grande problemática no que diz respeito às questões ambientais, sendo esta a falta de consciência por parte da população e dos diversos setores de produção. Uma medida a ser adotada para a minimização deste problema é a inserção da Educação Ambiental como disciplina nas escolas. Uma vez que a escola, na maioria das vezes, é mantenedora e reprodutora de uma prática dissociada da teoria e esta não surte resultados satisfatórios à preservação do meio ambiente, deve-se buscar mudanças e metodologias inovadoras que possam não só diminuir, mas introduzir uma cultura que traga consequências benéficas ao meio.

O artigo 225 da Constituição Federal de 1988 diz que "Todos têm direito ao meio ambiente ecologicamente equilibrado, bem de uso comum do povo e essencial à sadia qualidade de vida, impondo-se ao poder público e à coletividade o dever de defendê-lo e preservá-lo para as presentes e futuras gerações" (MEDAUAR, 2009).

Segundo o IBGE (2000 apud OLIVEIRA, 2010), o Brasil produz, atualmente, cerca de 228,4 mil toneladas de lixo por dia. O chamado lixo domiciliar equivale a pouco mais da metade desse volume, ou seja, 125 mil toneladas diárias. Do total de resíduos descartados em residências e indústrias, apenas 4.300 toneladas, ou aproximadamente $2 \%$ do total, são destinados à coleta seletiva. Quase 50 mil toneladas de resíduos são despejadas todos os dias em lixões a céu aberto, o que representa um risco a saúde e ao meio ambiente (OLIVEIRA, 2009).

Deve-se salientar que uma das grandes fontes poluidoras são as indústrias, uma vez que todo e qualquer processo de industrialização pode causar algum tipo de alteração no meio ambiente em decorrência dos resíduos gerados pelo seu processo produtivo, estes podem ser classificados em sólidos, líquidos e gasosos (NR 25, 1978), "os quais podem poluir/contaminar o solo, a água e o ar, sendo preciso observar que nem todas as indústrias geram resíduos com poder impactante nesses três ambientes" (PEREIRA, 2001).

As atividades humanas, as chamadas econômicas, são de grande importância para o setor da economia mundial, sendo também um dos setores que mais alteram o meio ambiente. Atualmente, existe uma preocupação relacionada aos problemas que acarretam impactos ambientais, que podem variar de acordo com o tipo de indústria, matérias-primas utilizadas, produtos fabricados, substâncias produzidas e descartadas e do próprio processo de produção. Portanto, todo e qualquer processo de industrialização pode causar algum tipo de alteração no meio ambiente, podendo ainda ser considerada maléfica ou benéfica (FILHO; GURGEL, 2012).

Algumas das muitas alternativas para a diminuição desses resíduos seria a implantação de um Sistema de Gestão Ambiental (SGA) para sua minimização na fonte poluidora, além do uso de Tecnologias Limpas, adoção à política da Redução, Reutilização e Reciclagem (política dos 3 R's), que baseia-se num conjunto de medidas de ação, em que "Reduzir" é o primeiro e mais importante passo e consiste na redução do uso de matérias-primas e do desperdício; "Reutilizar" é voltar a utilizar os produtos antes de jogá-los fora; e "Reciclar" é transformar os materiais inúteis em materiais úteis poupando energia e matéria-prima, entre outras (KANAYAMA, 1999).

Tendo isso em vista, o presente trabalho se propõe a identificar nas principais indústrias localizadas na cidade de Apodi/RN os principais resíduos descartados, através de uma avaliação realizada in loco, com questionários feitos com os responsáveis pelas mesmas e os funcionários. Como também, promover a prática da reciclagem e reutilização com os alunos da Escola Estadual Sebastião Gomes de Oliveira, acerca dos diversos resíduos gerados pelas indústrias da cidade, através de palestra e oficina realizadas na mesma.

\section{MÉTODO}

\section{I ANÁlise PRELIMINAR do GERENCIAMENTO dOS RESíduOS NAS INDÚSTRIAS DA CIDADE DE APODI/RN}

Após a análise das instrumentações teóricas, foi feita uma visita técnica in loco, às indústrias na cidade de Apodi/RN, denominadas nesse trabalho de Indústria A (Empresa de água mineral) e Indústria B (Empresa de Produtos Limpeza), a fim de realizar um diagnóstico das mesmas usando métodos de análise da qualidade de descartes de resíduos e o comportamento dos seus funcionários diante da ação, sempre levando em consideração as leis que a ANVISA (Agência de Vigilância Sanitária), o CONAMA 
(Conselho Nacional de Meio Ambiente) e os diversos outros órgãos que inspecionam este tipo de ação.

Para isso foi realizada uma entrevista semi-estruturada com perguntas abertas e fechadas aos funcionários e diretoria das indústrias, com o intuito de saber quais os tipos de resíduos gerados em seus processos produtivos, sobre a conscientização dos descartes desses resíduos, bem como os cuidados que são tomados em seu manejo.

Os questionários foram analisados de forma qualitativa, relacionando a teoria estudada com as práticas observadas nas indústrias. Essa análise serviu como fonte para estabelecer o grau de conscientização das empresas.

\subsection{Palestra e oficina na escola}

Foram realizadas atividades em formas de oficinas e palestras na Escola Estadual Sebastião Gomes de Oliveira, em uma turma de ensino médio, localizada na zona rural do município de Apodi/ $\mathrm{RN}$, com o objetivo de mostrar a importância da reutilização de resíduos em forma de artesanato, ou até mesmo para fins lucrativos. A palestra serviu para orientar os alunos dos tipos de resíduos que as indústrias da cidade produzem e o que elas podem fazer para reciclar, reaproveitar e reutilizar estes materiais de forma correta. Nas oficinas foram feitos novos produtos a partir do que é gerado e descartado pelas indústrias na forma de artesanato, como: garrafas, caixas de papelão, rótulos e sacos plásticos decorrentes do processo industrial.

Como forma de analisar a eficácia das produções com os alunos foi aplicado um questionário com o intuito de avaliar o que os mesmos aprenderam acerca do que foi exposto sobre o descarte correto dos resíduos, a importância da reciclagem e a conscientização que devemos ter a respeito do lixo que geramos.

\section{RESULTADOS E DISCUSSÃO}

As atividades humanas, as chamadas econômicas, são de grande importância para o setor da economia mundial, sendo também um dos setores que mais alteram o meio ambiente. Atualmente, existe uma preocupação relacionada aos problemas que acarretam impactos ambientais, que podem variar de acordo com o tipo de indústria, matérias-primas utilizadas, produtos fabricados, substâncias produzidas e descartadas e do próprio processo de produção. Portanto, todo e qualquer processo de industrialização pode causar algum tipo de alteração no meio ambiente, que pode ser maléfica ou benéfica (FILHO; GURGEL, 2012).

\section{I CARACTERIZAÇÃo E ANÁlISE de GERAÇÃo de RESíDUOS NA INDÚSTRIA A}

A Indústria A (empresa de água mineral) conta com aproximadamente 80 funcionários, divididos em 3 linhas de produção, onde as duas primeiras linhas funcionam em dois turnos de 6 horas por dia e na terceira linha apenas um turno de 8 horas.

Toda a linha de produção é de aço inox, o que evita a oxidação com possível contaminação da água. Para o bom funcionamento da empresa, a mesma possui 3 poços de água com aproximadamente $100 \mathrm{~m}$ de profundidade cada, onde um serve somente para a lavagem dos garrafões retornáveis de 20 $\mathrm{L}$, e os outros dois exclusivamente para o envase.

Para a lavagem dos garrafões, no que se refere a sua contaminação bacteriológica, é utilizado o ozônio, em que o mesmo é aplicado normalmente pouco antes do envase, esterilizando as paredes do garrafão. O ozônio não altera as características da água mineral, não deixa cheiro ou mau sabor, e ainda garante $100 \%$ de proteção sem interferir com a qualidade da água e sem deixar qualquer resíduo químico, visto que o mesmo se decompõe rapidamente em oxigênio.

Para um bom detalhamento do processo produtivo da indústria A, pode-se observar a Figura 1 que representa as etapas do mesmo. Onde,

1.Entrada dos Garrafões Retornáveis: Carros e caminhos terceirizados e da própria empresa deixam os garrafões para abastecimento;

2.Lavagem Manual: Feita com água oriunda de um dos poços. São retirados os lacres, rótulos e qualquer outro resíduo visto a olho nu;

3. Inspeção Visual e Odorífera: Os garrafões são separados. Os considerados bons são destinados 
à lavagem bactericida e germicida;

4. Túnel Bactericida e Germicida: Faz uso do ozônio para lavagem dos garrafões em concentrações pré-determinadas para não comprometer a qualidade do produto final;

5. Envase: Os garrafões saem da lavagem da lavagem por uma esteira e são posicionados mecanicamente na máquina de enchimento, que também efetua o tamponamento;

6. Colocação de Tampas, Lacres e Rótulos: O tamponamento é feito pela máquina de envase. As etapas seguintes são de colocação e fixação do lacre e do rótulo e de inspeção final;

7. Distribuição: Os carros que caminhões que deixaram os recipientes vazios na área de descarga, são abastecidos com o produto para efetuarem seu transporte.

da própria indústria, e a físico-química, que são feitas trimestralmente em laboratórios terceiri-

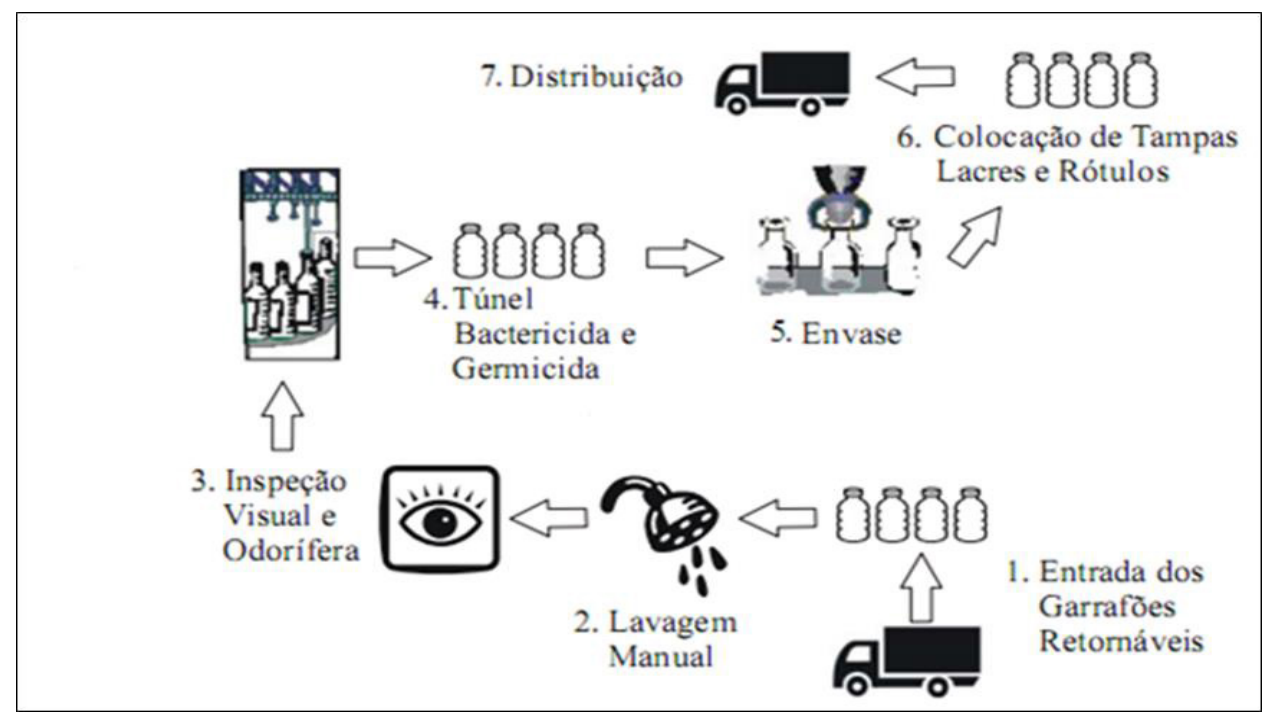

Figura 01 - Processo Produtivo da Indústria A

Para identificação dos principais resíduos gerados pela Indústria A foi realizada uma visita à empresa, na qual um dos responsáveis pela mesma, o Engenheiro Químico RPM, apresentou como se dá seu processo produtivo e quais seus respectivos resíduos, que são: garrafões de 20 litros, tampas, lacres, rótulos, água e papel de cultura.

Foi relatado que os garrafões utilizados no envase da água possuem validade de 3 anos, e que após esse período são enviados para empresas terceirizadas que trituram e fornecem esse material para fabricação de baldes nas cidades de Fortaleza-CE, João Pessoa-PB e Recife-PE. O material identificado neste garrafão é polipropileno (PP), um polímero com alta resistência química e a solventes.

Outro tipo de resíduo gerado na indústria em questão são as tampas, que por sua vez não deveriam voltar para a empresa, mas por consequência dos consumidores não fazerem a retirada e limpeza total dos garrafões antes do uso, elas retornam junto com os garrafões para reabastecimento, e são retiradas. Essas tampas quando virgens são enviadas para fábricas de bonés e garrafões, para o endurecimento do mesmo. Para selar as tampas são utilizados lacres, configurando-se assim outro tipo de resíduo.

No processo de produção observou-se que a indústria utiliza bastante água, desde a lavagem inicial quando os garrafões chegam para reabastecimento, na lavagem bactericida até o envase. A água de lavagem é reutilizada para a irrigação da área verde que a empresa possui e também nas caixas de água dos banheiros dos funcionários, havendo um reaproveitamento da mesma.

Os rótulos são mais um tipo de resíduos gerados pela empresa, e são tratados como o "resíduo problema", visto que ainda não se encontrou um fim adequado para estes. Já foram feitos testes para misturar o papel com cimento, para ser utilizado no setor de construção, mas não obtiveram muito êxito, sendo este processo inviável por ser de alto custo. Atualmente, partes destes rótulos são utilizados para preenchimento de almofadas e a outra é descartada no lixo comum.

Nesta visita, identificou-se que a empresa realiza as análises necessárias em seu roduto antes da sua distribuição. As principais análises são a bacteriológica, por meio de cultura, feita no laboratório 
zados. Segundo ABNT (2007 apud Medeiros, 2008) a Resolução - RDC nº 54 de 15 de junho de 2000 define padrões microbiológicas para as águas minerais, na fonte, poço ou local de surgência e na sua comercialização. Elas devem estar ausentes de microrganismos patogênicos e estar em conformidade com as características descritas na norma.

$\mathrm{Na}$ análise bacteriológica foi identificado um tipo de resíduo, sendo este, o papel que é utilizado para a cultura. Após a análise, o papel passa por processo de autoclavagem a fim de eliminar a cultura em questão. Feito todo este processo, o papel está adequado para ser descartado no lixo comum.

A Tabela 1 a seguir apresenta todas as etapas do processo produtivo da empresa bem como todas as suas entradas e saídas de materiais e resíduos.

Outra atividade realizada durante a visita foi uma entrevista com quatro funcionários de dife-

Tabela 01 - Etapas do processo produtivo da Indústria A com entradas e saídas

\begin{tabular}{|c|c|c|}
\hline ETAPAS & ENTRADAS & SAÍDAS \\
\hline $\begin{array}{l}\text { Preparação } \\
\text { dos garrafões }\end{array}$ & $\begin{array}{l}\text { Garrafões que retornam do } \\
\text { mercado }\end{array}$ & $\begin{array}{l}\text { Resíduos de rótulos } \\
\text { Resíduos de tampas } \\
\text { Resíduos de lacres } \\
\text { Água de lavagem }\end{array}$ \\
\hline Lavagem manual & $\begin{array}{l}\text { Água para lavagem manual } \\
\text { dos garrafões }\end{array}$ & Água contaminada \\
\hline $\begin{array}{l}\text { Passagem dos } \\
\text { garrafões pelo túnel } \\
\text { bactericida }\end{array}$ & $\begin{array}{l}\text { Água mineral ozonizada } \\
\text { Energia elétrica }\end{array}$ & $\begin{aligned} & \text { Água mineral } \\
& \text { contaminada }\end{aligned}$ \\
\hline Envase & Água Mineral & $\Rightarrow$ Perda de água mineral \\
\hline $\begin{array}{l}\text { Tamponagem } \\
\text { automática }\end{array}$ & Tampas de polipropileno & Tampas de polipropileno \\
\hline $\begin{array}{l}\text { Colocação dos lacres } \\
\text { (manual) }\end{array}$ & Lacres & $\Rightarrow$ Lacres \\
\hline $\begin{array}{l}\text { Rotulagem e } \\
\text { inspeção visual }\end{array}$ & Rótulos & $\Rightarrow$ Rótulos \\
\hline
\end{tabular}

rentes setores de produção da indústria, a fim de saber se os mesmos tinham o conhecimento de quais os resíduos que a empresa a qual eles trabalham gera, bem como seu entendimento acerca da forma correta de se descartar os resíduos gerados e ainda o interesse em saber mais sobre este assunto.

De uma forma geral os funcionários são conhecedores de quais são os resíduos que a empresa gera, mas não tem um conceito formado sobre o que é resíduo, apenas ideias. Ainda puderam identificar quais os tipos de tratamento pelo qual os mesmos passam, ressaltando que a maneira como a empresa procede diante desta atividade, é correta, como afirmou IFS "é correto, porque é melhor levar para reciclagem para fazer coisas novas". 
Em um segundo momento foi questionado se eles tinham a consciência que o descarte incorreto do lixo pode vir a gerar problemas ambientais, e por consequência afetar sua família, e todos se mostraram interessados em obter mais informações sobre como descartar corretamente não só os resíduos gerados na empresa, mas também em suas residências, como relatou MAFM "é muito interessante sabermos como descartar certos materiais em nossas casas como pilhas, carregadores de celular, baterias, por que muitas pessoas não sabem e acabam jogando no lixo comum"

As embalagens plásticas provêm de garrafas defeituosas e materiais de armazenamento de As As embalagens plásticas provêm de garrafas defeituosas e materiais de armazenamento de matéria-prima

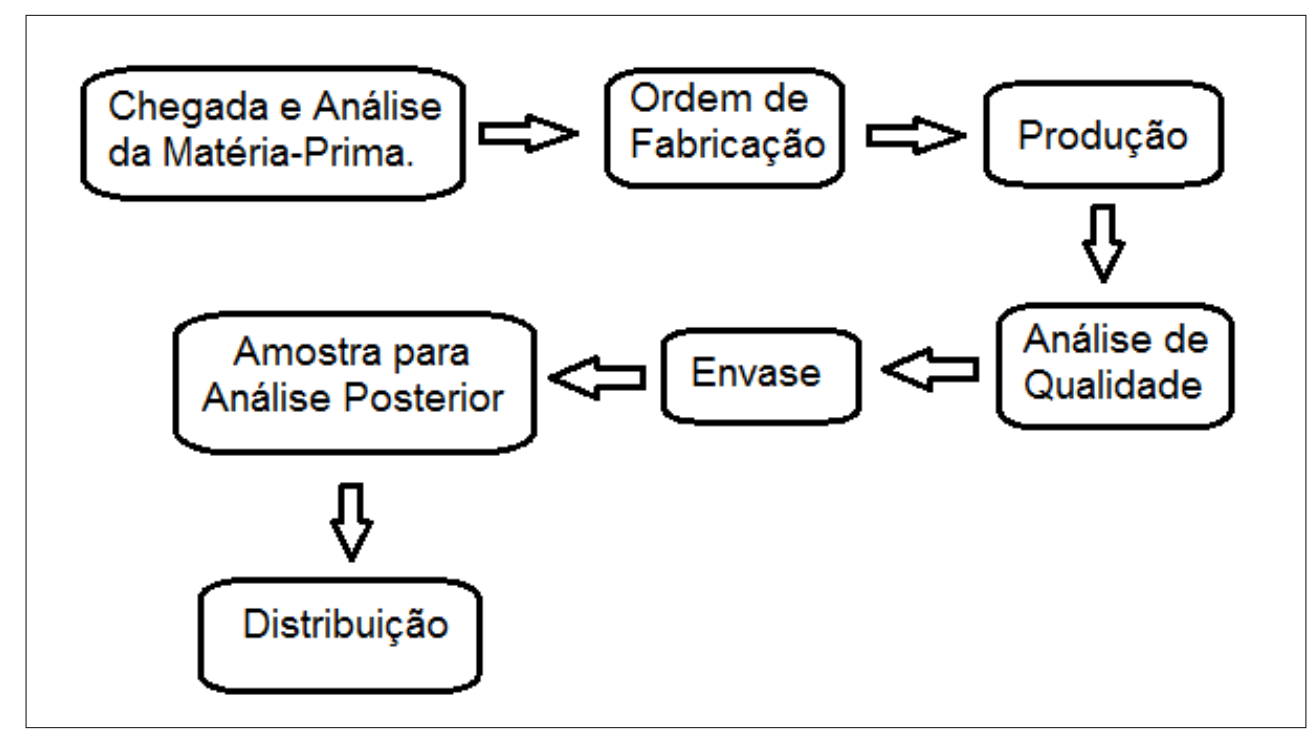

Figura 02 - Processo Produtivo da Industria B

\subsection{CARActerização E ANÁLISE de GeraÇão de RESíduOS NA INDÚSTRIA B}

A Indústria B conta com 23 funcionários de forma geral, sendo que 18 deles trabalham na área de produção e os outros 5 no setor de venda, entrega, carga e descarga. O horário de funcionamento é de 8 horas diária, dividindo-se em dois turnos, 4 horas cada um.

A Figura 2 é um representativo do processo produtivo da indústria.

As etapas do fluxograma podem ser descritos da seguinte forma:

- Chegada e Análise da Matéria-Prima: Quando a matéria-prima chega, ela passa por um processo de análise visual, passando 48 horas em observação em um local separado;

- Ordem de Fabricação: A diretoria da indústria emite as ordens de fabricação dos produtos de acordo com a demanda que chega do setor de vendas, esta ordem vem com as quantidades e os tipos de produtos;

- Produção: Produzem aquilo que foi encaminhado pela ordem de fabricação.

- Análise de Qualidade: Realização de testes determinados pela ANVISA para o controle de qualidade do produto;

- Envase: Cada produto tem seu tanque específico e sua tubulação, e o envase é feito de forma manual;

- Amostra para Análise Posterior: É coletada uma amostra de cada lote fabricado para uma análise visual (mudança de cor e de características), esta é feita até o final do período de validade do produto;

- Distribuição: A distribuição é feita pelo setor de vendas em atacado e varejo.

Para a identificação dos resíduos gerados pela Indústria B, também foi realizada uma visita in loco, onde na ocasião quem acompanhou em todo o processo foi o Químico responsável, HDSD. Os principais resíduos identificados na visita foram: embalagens plásticas, papelão, rótulos, tampas, sacos de ráfia (bague) e resíduos líquidos. 
(tambor de 200 litros), o último é o resíduo mais preocupante da empresa, pois ainda não se achou um fim adequado para o mesmo. A indústria já entrou em contado com uma empresa terceirizada que recolhe esse tipo de material, mas devido a distância se tornou inviável para o seu envio.

Uma das embalagens plásticas utilizadas é uma garrafa de 5 litros. Como forma de ação visando a minimização do custeio do produto e a redução na geração de resíduo foi adotada uma política de reuso, funcionando da seguinte maneira: o cliente que trouxer a garrafa vazia teria um real de desconto na compra de outra. Esta política na visão da ANVISA é incorreta, pois a mesma proíbe o reuso destas embalagens que impossibilitou a continuidade do processo.

Os rótulos provêm de garrafas defeituosas ou de algum problema com o mesmo. Quando isto acontece, a indústria os envia para uma fundação que faz parte do mesmo grupo empresarial, Fundação Dário Penha, que recebe crianças residentes no entorno da empresa para realizar algumas atividades artesanais, como a reciclagem de materiais: garrafas plásticas, tampas, etc. Os begues chegam à indústria com as pré-formas, e são reutilizadas para o armazenamento das garrafas sopradas antes do envase.

Todo o resíduo líquido gerado pela empresa é acondicionado em uma fossa séptica, localizada no interior da mesma, com capacidade para 100 mil litros. A fossa é desgotada sempre que atinge sua capacidade máxima, mas o controle que deveria ser feito com esse efluente não acontece, pois é um trabalho feito por uma equipe terceirizada. Estes resíduos são provenientes da lavagem de tanques e encanamentos, sobras da produção e as amostras coletadas para análise depois do período de validade. Depois de alguns testes, a indústria constatou que ao misturar $10 \%$ do produto fora do prazo de validade ao produto que está sendo fabricado, não houve mudança em seu produto final, atingindo o mesmo padrão de qualidade.

Nas análises microbiológicas e físico-químicas, realizadas na empresa, não observou-se geração de nenhum tipo de resíduo, pois estas são feitas em parcerias por empresas terceirizadas uma vez por ano.

A Tabela 2 mostra todas as etapas do processo produtivo da referente empresa, bem como todas as suas entradas e saídas de materiais e resíduos.

Assim como na Indústria A foi realizada uma entrevista com quatro funcionários de diferentes

Tabela 02 - Etapas do processo produtivo da B com suas entradas e saídas

\begin{tabular}{|c|c|c|}
\hline ETAPAS & ENTRADAS & SAÍDAS \\
\hline $\begin{array}{l}\text { Recebimento de } \\
\text { matéria-prima }\end{array}$ & Matéria-prima e materiais & -- \\
\hline Armazenagem & $\begin{array}{l}\text { Materiais de embalagens } \\
\text { Energia elétrica }\end{array}$ & $\begin{array}{l}\text { Restos de embalagens } \\
\text { (plástico, papelão } \\
\text { bombonas) }\end{array}$ \\
\hline $\begin{array}{l}\text { Pesagem e separação } \\
\text { de matérias-primas }\end{array}$ & $\begin{array}{l}\text { Materiais de embalagens } \\
\text { Matérias-primas } \\
\text { Energia elétrica }\end{array}$ & $\begin{array}{l}\text { Restos de embalagens } \\
\text { Resíduos líquidos }\end{array}$ \\
\hline Produção & $\begin{array}{l}\text { Materiais de embalagens } \\
\text { Matérias-primas } \\
\text { Energia elétrica } \\
\text { Insumos auxiliares }\end{array}$ & $\begin{array}{l}\text { Restos de embalagens } \\
\text { Resíduos líquidos } \\
\text { Emissões atmosféricas }\end{array}$ \\
\hline Testes em laboratório & $\begin{array}{l}\text { Materiais de laboratório } \\
\text { Produtos químicos }\end{array}$ & $\begin{array}{l}\text { Resíduos de amostras } \\
\text { analisadas } \\
\text { Soluções fora da validade } \\
\text { ou contaminadas }\end{array}$ \\
\hline Envase/embalagem & $\begin{array}{l}\text { Materiais de embalagem } \\
\text { Frascos e potes de plástico } \\
\text { Energia elétrica } \\
\text { Insumos auxiliares } \\
\text { Rótulos }\end{array}$ & $\begin{array}{l}\text { Restos de embalagens } \\
\text { Frascos e potes com } \\
\text { defeito } \\
\text { Resíduos líquidos } \\
\text { Resíduos de adesivos }\end{array}$ \\
\hline $\begin{array}{l}\text { Armazenamento do } \\
\text { produto acabado }\end{array}$ & Materiais de embalagem & $\begin{array}{l}\text { Restos de embalagens } \\
\text { Resíduos de varrição de } \\
\text { pisos } \\
\text { Produtos vencidos, } \\
\text { devolvidos ou }\end{array}$ \\
\hline
\end{tabular}


setores em B. Percebeu-se que os funcionários têm uma grande clareza no que se diz respeito às questões ambientais, e ainda entendem que o mau gerenciamento e o descarte incorreto dos resíduos que a empresa gera pode acarretar danos ao meio ambiente. Quando questionados sobre o que entendiam por resíduos, observou-se um bom conhecimento do assunto. Em uma delas, ARM diz que "é tudo aquilo que causa algum impacto de alguma forma, vindo a poluir, alterando assim o meio ambiente".

Todos os funcionários puderam identificar os resíduos gerados pela indústria, bem como o descarte que a mesma realiza e a forma de tratamento adequada para cada um. Ainda souberam discorrer sobre os resíduos sólidos dos líquidos, opinando no descarte que a empresa faz a respeito dos efluentes, como ressaltou ARM sobre o assunto:

"Os resíduos líquidos vão todos para uma fossa séptica e uma empresa terceirizada é contratada para esvaziá-la. Sabemos que esse procedimento é errado, mas a empresa não pode parar, nós temos que ir nos adequando aos poucos por que não temos condições. O ideal é uma estação de tratamento de efluentes (ETE) para pelo menos tirar os resíduos mais pesados."

Ao decorrer da entrevista, percebeu-se que o grau de consciência dos empregados é relevante, pois demonstram preocupação no que diz respeito à geração e descarte correto do lixo, e que o mesmo descartado de forma incorreta pode causar grandes danos tanto ao meio ambiente como a sua própria família. Ao serem questionados sobre o interesse de conhecer mais sobre o assunto, afirmaram que sim, pois "há uma necessidade, visto que quem trabalha nesse setor é sempre bom estar buscando formas de diminuir a geração de resíduos", afirmou MRS.

\subsection{Atividade na escola Sebastião Gomes}

Após observação dos principais resíduos das Indústrias da Cidade, dirigiu-se as atividades a Escola Estadual Sebastião Gomes de Oliveira, localizada na zona rural do município de Apodi/RN. Participaram do momento 12 alunos da $2^{a}$ série do Ensino Médio da referida escola, o encontro aconteceu no turno noturno e teve duração de 2 (duas) horas.

O encontro com os alunos foi divido em duas etapas. Na primeira etapa foi realizada uma palestra com o intuito de mostrar a definição de resíduos em geral, a classificação dos mesmos, enfocando nos resíduos industriais que é o alvo do projeto, reforçou-se ainda a política dos 5 R's, como também foi mostrado as formas de reciclagem. Na mesma palestra, ainda foi mencionado as principais indústrias da cidade, enfatizando duas anteriormente avaliadas.

Ainda se tratando do primeiro momento da palestra, foi exposto os principais resíduos gerados por essas empresas nos seus processos produtivos, bem como as formas de descarte que as mesmas utilizam.

Em segunda instância, foi iniciada uma oficina com o objetivo dos alunos fabricarem materiais alternativos através da reutilização dos resíduos gerados pelas indústrias. Para a realização da oficina, foram disponibilizados os seguintes materiais: Tinta guache, pincel, tesoura, cola quente, prego, martelo, serra, e os resíduos: garrafões, papelão, rótulos, plásticos, garrafas de produtos de limpezas e papel.

Os alunos foram incentivados a realizarem suas próprias criações utilizando a criatividade e produzindo materiais a serem utilizados em suas residências (Figura 3).

A construção dos materiais reaproveitados ocorreu de forma satisfatória, tendo em vista que

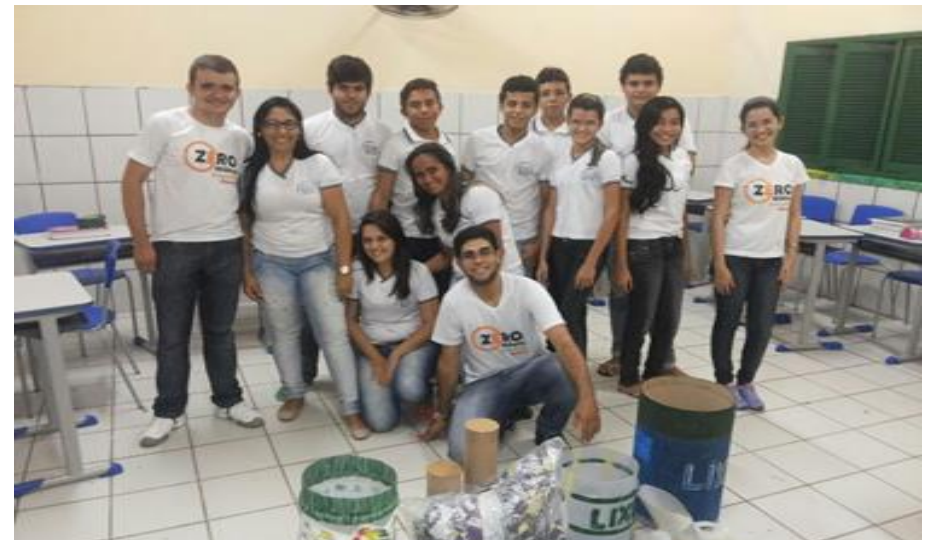

Figura 03 - Confecção dos materiais reaproveitados 
todos deram sua contribuição. Durante a confecção, os alunos demonstraram um grande interesse em criar novos materiais, com entusiasmo e dedicação, isso foi visto a partir dos produtos obtidos, onde se pôde notar a criatividade dos estudantes ao fabricarem seus objetos. A Tabela 3 apresenta os materiais recolhidos nas indústrias, que serviram de partida para a confecção de todos os materiais reaproveitados produzidos pelos alunos.

Durante o encontro, foi feita ainda uma demonstração de como reciclar o papel residual de Tabela 3 - Alguns materiais de partida e seus respectivos produtos

\begin{tabular}{ll}
\hline \multicolumn{1}{c}{ Resíduos utilizados } & \multicolumn{1}{c}{ Materiais produzidos } \\
\hline Garrafão de 20 litros e tambor de papelão & Lixeiras e jarros para plantas \\
\hline Cilindro de papelão & Cofres/porta moedas \\
\hline Garrafas de amaciante e desinfetante & Porta-lápis e brinquedos \\
\hline Rótulos e sacos plásticos & Almofada \\
\hline Papelão & Porta retrato \\
\hline
\end{tabular}

suas atividades escolares. No procedimento observou-se grande interesse de como se deve proceder. Alguns deles fizeram questionamentos sobre a coloração do papel reciclado, se o mesmo não ficaria quebradiço, e alguns disseram que iria colocar em prática este processo.

A fim de avaliar o que os alunos absorveram da palestra e oficina realizadas na escola, foi aplicado um questionário. Responderam a este questionário 11 alunos, correspondendo a $92 \%$ dos que participaram do momento. Os gráficos a seguir mostram alguns dos resultados coletados (Figuras 4-6). Analisando os dados acima, percebe-se que a palestra juntamente com a oficina foi de grande

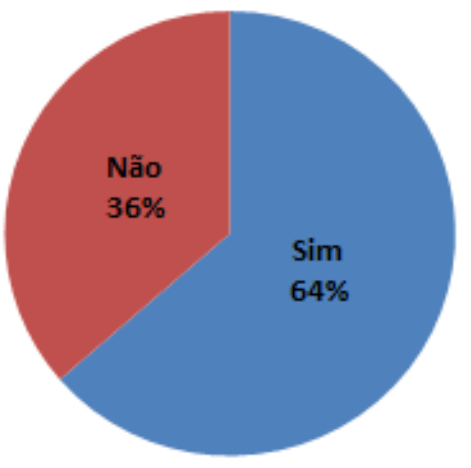

Figura 04 - Questionamento sobre a utilização do material produzido pela oficina

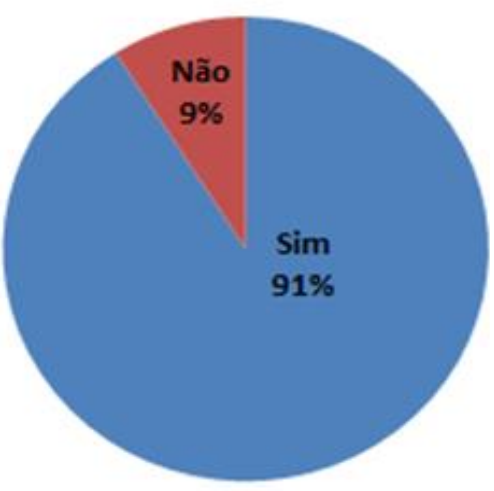

Figura 05 - Questionamento sobre a mudança no ponto de vista em relação ao desperdício após a palestra 


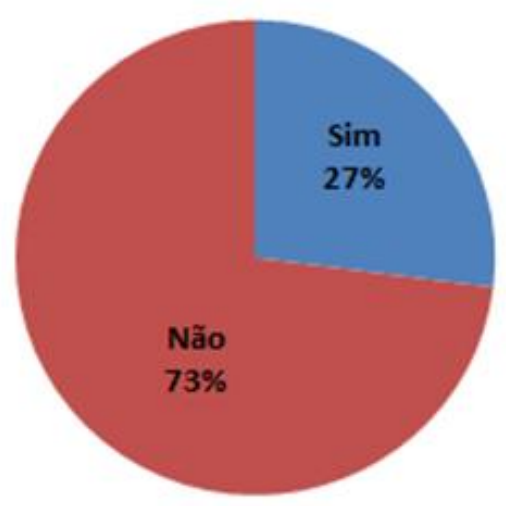

Figura 06 - Questionamento sobre o incentivo da prática dos 3 R's na comunidade

importância para os alunos daquela comunidade uma vez que, através do questionário, eles afirmaram que compreenderam a seriedade do assunto em questão. Um dos questionamentos que chamou atenção, foi o fato de que os mesmos apesar de entenderem que as questões ambientais necessitam de uma atenção e cuidado maior, não incentivam seus familiares e a comunidade local a fazerem o correto, que é o não desperdício, a reciclagem, o descarte correto de seu lixo, dentre outras coisas.

Os alunos ressaltaram muito a questão do desperdício, que muitos dos materiais que achavam que não tinha mais nenhuma utilidade podem ser reutilizados de forma útil, necessitando apenas de sua criatividade o que mostra a importância de atividades como essa que devem ser contínuas no meio escolar.

\section{CONCLUSÃO}

Pensar nas questões ambientais deve ser uma preocupação comum a todas as empresas, visto que o setor industrial é um dos que mais gera resíduos. De acordo com as observações e pesquisas realizadas, percebe-se que as indústrias em estudo demonstram uma preocupação com as questões ambientais, realizando ações que comprovam tal preocupação, como: reutilização de materiais, descarte correto de resíduos, busca de parcerias, etc.

Mediante os resultados obtidos, é notório que o ambiente escolar é um local apropriado para desenvolver esse tipo de atividade, visto que, os alunos estão em um processo continuo de aprendizagem, e é na escola que acontece a formação do caráter crítico e responsável, pois estes exercerão grande influência nas suas tomadas de decisões futuras.

Desta forma, espera-se que, com este trabalho, ter contribuído de uma forma ou de outra para com a formação dos alunos, para que os mesmos tenham uma educação ambiental e que saibam dar uma continuidade a esse processo, repassando para seus familiares, colegas e na comunidade em que estão inseridos. Com o intuito de proporcionar os envolvidos a terem conhecimentos, valores, habilidades e atitudes necessárias para proteger o meio ambiente.

\section{AGRADECIMENTOS}

Os autores agradecem a colaboração das empresas em permitirem tão cordialmente a realização do trabalho.

\section{REFERÊNCIAS}

FILHO, J. L. O. P; GURGEL, L. L. Impactos Socioambientais das Indústrias Da Cal, no Distrito de Soledade Do Município De Apodi - RN. Revista de Gestão Social e Ambiental - RGSA, São Paulo, v. 6, n. 1, p. 87-101, jan./abr. 2012. 
KANAYAMA, P. H. Minimização de Resíduos Sólidos Urbanos e Conservação de Energia. Dissertação (Mestrado) - Escola Politécnica da Universidade de São Paulo. Departamento de Engenharia de Energia e Automação Elétrica. São Paulo, 1999.

MEDAUAR, O. (org.). Coletânea de Legislação Ambiental, Constituição Federal. - $8^{a}$ ed. rev., ampl. e atual. São Paulo: Editora Revista dos Tribunais, 2009. - (RT MiniCódigos).

MEDEIROS, M.U.N. Sistema de Gestão Ambiental na Produção de Água Mineral. 2008. 120 f. Tese submetida ao Programa de Engenharia de Produção da Universidade Federal do Rio Grande do Norte como requisito do grau de Mestre em Ciências em Engenharia de Produção. Natal-RN, 2008.

NR 25 - Resíduos Industriais. Portaria GM n. ${ }^{\circ}$ 3.214, de 08 de junho de 1978.

OLIVEIRA, C. F. R.; BASTOS, A. L.; SANTOS, V. R.; GAMA, J. A. S. Diagnóstico Ambiental De Uma Empresa De Água Mineral Do Estado De Alagoas. IV Congresso de Pesquisa e Inovação da Rede Norte Nordeste de Educação Tecnológica - CONNEPI, Belém/PA, 2009.

OLIVEIRA, P. A. Conceitos de Redução, Reutilização e Reciclagem Aplicados na Gestão Ambiental do Lixo Domiciliar (ou Residencial) Urbano. 2010. 52 f. Monografia apresentada ao Instituto A Vez do Mestre Universidade Candido Mendes como requisito do grau de especialista em Gestão Ambiental. Rio de Janeiro, 2010.

PEREIRA, J. A. R. Geração de resíduos industriais e controle ambiental. Saber, v.3, p.121 - 139, 2001. 